\title{
On metallocene-containing macromolecules and their applications
}

\author{
Haibin Gu, ${ }^{a}$ Roberto Ciganda, ${ }^{b, c}$ Sylvain Gatard, ${ }^{b}$ Feng Lu, ${ }^{b}$ Pengxiang Zhao, ${ }^{d}$ Jaime Ruiz, ${ }^{b}$ \\ Didier Astruc ${ }^{b^{*}}$
}

${ }^{a}$ Key Laboratory of Leather Chemistry and Engineering of Ministry of Education, Sichuan University, Chengdu 610065, P. R. China

${ }^{\mathrm{b}}$ ISM, UMR CNRS N ${ }^{\mathrm{o}}$ 5255, Univ. Bordeaux, 33405 Talence Cedex, France

${ }^{c}$ Facultad de Quimica de San Sebastian, Universidad del Pais Vasco, Apdo 1072, 20080 San

Sebastian, Spain

${ }^{\mathrm{d}}$ Science and Technology on Surface Physics and Chemistry Laboratory, PO Box 718-35, Mianyang 621907, Sichuan, P. R. China

\section{Email : d.astruc@ism.u-bordeauxl.fr}

\begin{abstract}
A remarkable property of metallocenes, in particular those of the late first-row transition metals, is their redox function including the stability of two or several oxidation states. Recently our groups have introduced these compounds into precise dendrimers and polymers in view of sensing and catalytic applications. This short overview essentially focuses on the synthetic aspects and applications of our research conducted in this area.
\end{abstract}

Keywords: ferrocene, cobalticinium, ROMP copolymer, dendrimer, redox activity

\section{Introduction}

The discovery of ferrocene and other metallocenes and $\pi$-complexes [1] has marked the very beginning of modern organometallic chemistry $[1,2]$, and it has been rapidly followed by the introduction of ferrocene into polymers [3]. The redox aspects of transition metal organometallics [4,5], exemplified by the work of Professor Heinrich Lang's group in molecular electronics [6], are indeed essential for their applications, as shown with the early biomedical applications of ferrocene-modified pyrrole polymers as glucose sensors [7]. In the late first-row transition metal metallocenes, single electron transfer chemistry including stable 17- and 19-electron organometallic radicals dominate [8], which is not the case for the chemistry of second and third row counterparts [2]. These redox properties have been introduced in ferrocene- and cobalticinium-containing polymers for several decades with materials applications such as sensors [9-11]. More recently, specific topologies of precise metallocene-containing dendrimers [12,13] and ROMP polymers [14] have appeared, in particular with click metallodendrimers [15] and metallocene-containing living polymers and co-polymers synthesized by ring-opening metathesis polymerization (ROMP) using Grubbs' $3^{\text {rd }}$ generation catalyst [16]. These new families and their properties that have been the subject of recent research in our laboratory will be discussed in this overview article. 


\section{Living polymers and copolymers containing late transition metal sandwich units}

Metallopolymers have attracted considerable interest because of their physical properties that provide applications in catalysis [17] including electrocatalysis [18], sensing [7,19], responsive surfaces [20], capsules [21], photonic crystal displays [22], lithography [23], magnetism [24], electrochromism [25] and ceramic precursors [26], and these properties and applications have been recently reviewed [27]. Following a starting period marked by the syntheses of various ferrocene-containing polymers with poor definition and polydispersities [27a], the discovery by the Manner group in 1992 that strained ring-tilted ferrocenophane undergo, under a variety of stimuli (thermal, ionic, photolytic, catalytic), ring-opening polymerization (ROP) that can eventually be living, was a real breakthrough in metallopolymer chemistry, because these well-defined materials led to a variety of original electronic, mechanical, optic and magnetic properties, and the polymerization principle could be extended to a variety of metal-sandwich complexes $[9,10,28]$. Recently, we introduced a new effective method to introduce functional metal sandwich units in the main polymer chain using the well-known $\mathrm{Cu}^{\mathrm{I}}$-catalyzed alkyne azide cycloaddition (CuAAC), the best known among "click" reactions. With such a strategy, the polymerization is not living, but the presence of the 1,2,3-triazolyl groups in these metallopolymers offers the possibility to coordinate the cyclic nitrogen ligands to transition metal cations. This allows not only the possibility of redox recognition of these transition-metal cations by cyclic voltammetry but also the reduction of these coordinated cations to polymer-stabilized metal nanoparticles that disclose specific physico-chemical and catalytic properties [29]. For instance, the click reaction between bis(ethynyl)biferrocene and bis(azido) molecules yielded redox polymers disclosing multiple properties including electrochrome, polyelectrolyte, sensor, electrode modifier, nanoparticle stabilizer and catalyst template [30].

Besides these metallopolymers containing metal-sandwich units in the main chain, there are numerous reports of polymers containing ferrocene or other metal-sandwich units in the side chain. These polymers are synthesized either by polymerization of a metallocene-containing monomer or by post-functionalization with a metallocene unit of a functional polymer, and the literature has been recently reviewed [27a]. Most remarkably, several modern polymerization techniques have provided well-defined polymers with predetermined molecular weights, low polydispersities and high functionalities by living polymerization: (i) living anionic polymerization (LAP) [31], (ii) ring-opening metathesis polymerization (ROMP) [32] using the most active group 6 and group 8 metal catalysts [16], and (iii) controlled radical polymerization (CRP) techniques [33] that include atom transfer radical polymerization (ATRP) [34], reversible addition-fragmentation chain transfer polymerization (RAFT) [35] and nitroxide-mediated polymerization (NMP) [36]. Although well-defined metallocene-containing polymers have been synthesized with all these techniques [27a], we focus here on ROMP following our interest for such olefin metathesis reactions $[3,16 \mathrm{c}]$.

The most active catalysts for controlled living polymerization are Schrock's molybdenum and tungsten imido alkylidene complexes [37] and Grubbs' 3rd generation metathesis catalyst, 
namely ruthenium benzylidene $N$-heterocyclic carbene bis $m$-chloropyridine complex $\mathbf{1}$ (Figure 1) [16,38].

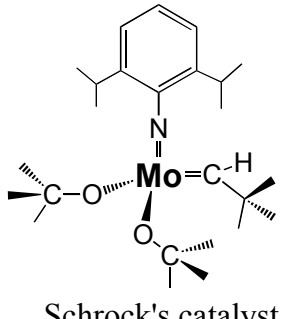

Schrock's catalyst

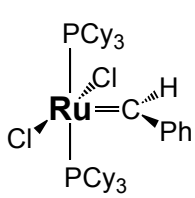

Grubbs'

$1^{\text {st }}$-generation catalyst

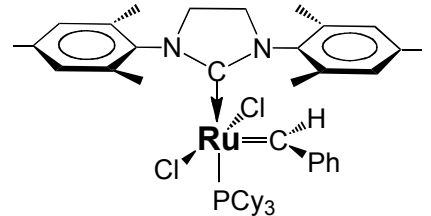

Grubbs'

$2^{\text {nd }}$-generation catalyst

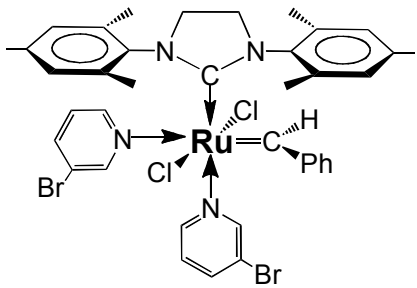

Grubbs' $3^{\text {rd }}$-generation catalyst

Figure 1. ROMP metathesis catalysts.

The former complexes are air sensitive with limited tolerance to functional groups, whereas the latter complex $\mathbf{1}$ is more tolerant and is being generally used by polymer chemists for this purpose. Thus for instance various living ferrocene-containing polymers such as $\mathbf{2}$ and block copolymers have been synthesized using this ruthenium catalyst [11,14,39-41] (Scheme 1).
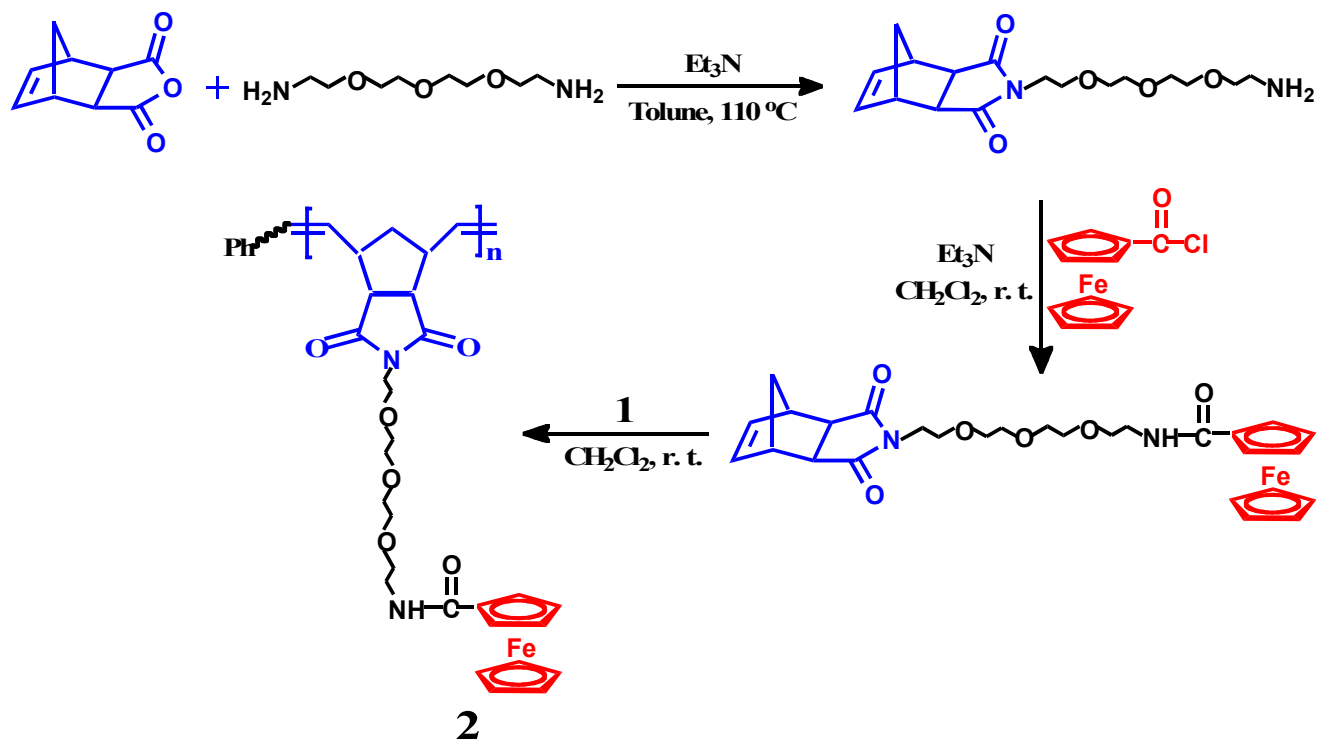

Scheme 1. ROMP synthesis of a living amidoferrocene-containing polymer 2 using the catalyst 1 [41a].

Cobalticinium that is isoelectronic with ferrocene [42] has been functionalized first by carboxy substituents [42b] then more recently with the very useful ethynyl substituent [43] for further click chemistry [43a,b] or reaction with amines [43b] (Scheme 2). These functional groups led to the synthesis of cobalticinium-containing polymers [40c,44]. 


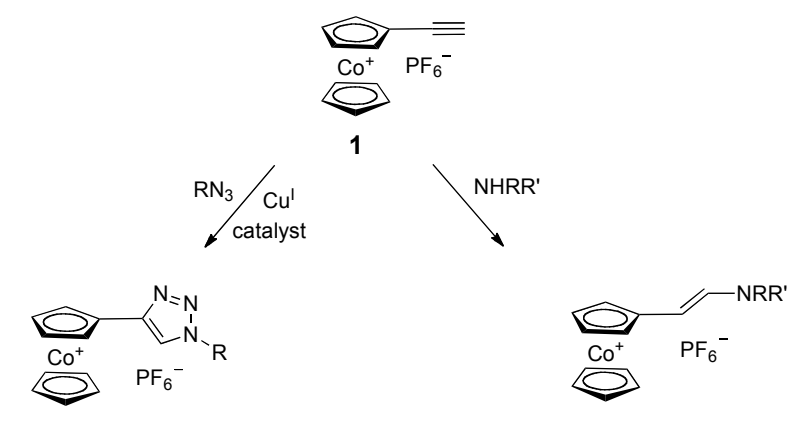

Scheme 2. Two useful reactions of ethynylcobalticinium in view of further functionalization in macromolecules [43].

For instance ROMP using Grubbs' $3^{\text {rd }}$ generation catalyst allowed the synthesis of cobalticinium polymers either by ROMP of a cobalticinium-containing monomer or by functionalization with the cobalticinium monomer of a functional polymer [44c] (Scheme 3).

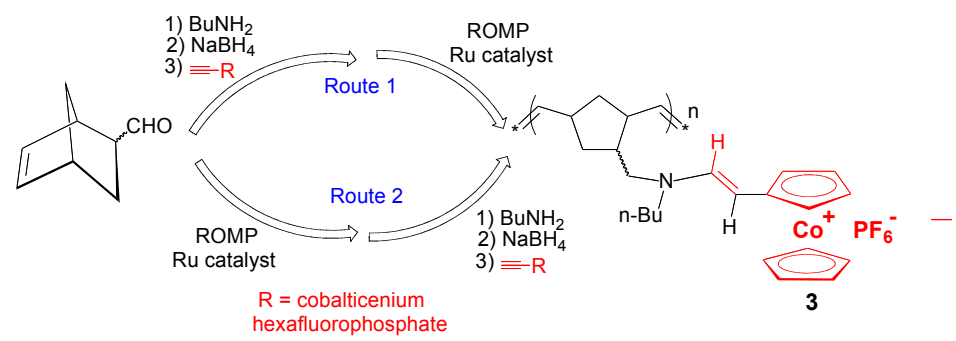

Scheme 3. Two routes to cobalticinium-containing polymers either by ROMP of a cobalticinium-containing norbornene monomer (top, route 1) or by post-click functionalization with ethynylcobalticinium of an azido functionalized norbornene polymer (bottom, route 2) [44c].

The cyclopentadienyl-iron-arene family is another series of metal sandwich complexes that has a rich functional chemistry [45-47] allowing its introduction into polymers by efficient nucleophilic substitution of one or two chloro substituents on the arene ligand of the 18electron cationic form $[45,47]$ that is thermally robust, but more or less sensitive to visible light $[45,48]$. Thus efficient polymerizations including ROMP reactions with Grubbs' ruthenium metathesis catalysts were elegantly achieved by Abd-El-Aziz' group [11a,27a,47]. Although cyclic voltammetry of the 18 -electron cations $\left[\mathrm{FeCp}\left(\mathrm{h}^{6} \text {-arene) }\right]^{+}\right.$reversibly provides neutral 19-electron $\mathrm{Fe}(\mathrm{I})$ species [49], the latter are not long-lived enough for ready isolation if the arene is not protected by permethylation in the hexamethylbenzene ligand [50]. Indeed, the complexes $\left[\mathrm{Fe}\left(\eta^{5}-\mathrm{C}_{5} \mathrm{R}_{5}\right)\left(\eta^{6}-\mathrm{C}_{6} \mathrm{Me}_{6}\right)\right]^{\mathrm{n}+}(\mathrm{n}=0-2, \mathrm{R}=\mathrm{H}$ or Me $)$ are thermally stable in the three oxidation states I, II, and III [51], which provide favorable conditions for their incorporation into polymers. Therefore living norbornene polymers synthesized by ROMP using Grubbs' $3^{\text {rd }}$ generation catalyst and containing the redox-robust complex $\left[\mathrm{FeCp}\left(\mathrm{h}^{6}-\right.\right.$ $\left.\left.\mathrm{C}_{6} \mathrm{Me}_{6}\right)\right]\left[\mathrm{PF}_{6}\right]$ in the side chain were recently reported [41b] (Scheme 4). 


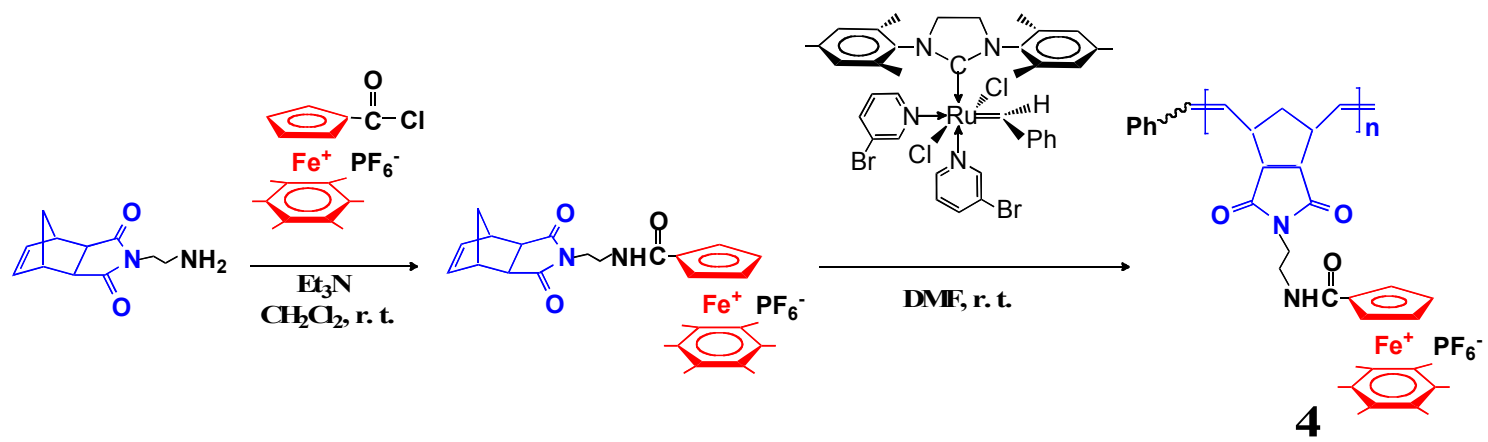

Scheme 4. ROMP synthesis of a polymer 4 containing the redox-robust complex $\left[\mathrm{FeCp}\left(\mathrm{h}^{6}-\right.\right.$ $\left.\left.\mathrm{C}_{6} \mathrm{Me}_{6}\right)\right]\left[\mathrm{PF}_{6}\right]$ in the side chain $[41 \mathrm{~b}]$.

Among the advantages of the living polymerization techniques, a critical one is the possibility to synthesize well-defined di- or polyblock polymers in which each block brings about specific properties including magnetism, polyelectrolytes, nanoparticles, catalysis, etc. [1726,39-41]. For instance, this method allowed introducing two distinct metal sandwich units in these diblock polymers synthesized by ROMP, such as polymers containing both ferrocenecontaining block and a cobalticinium-containing block [41d] or two block containing distinct cationic transition-metal sandwich complexes such as cobalticinium and $\left[\mathrm{FeCp}\left(\mathrm{h}^{6}\right.\right.$ $\left.\left.\mathrm{C}_{6} \mathrm{Me}_{6}\right)\right]\left[\mathrm{PF}_{6}\right]$ in the diblock metallopolymer 5 [41e] (Scheme 5).

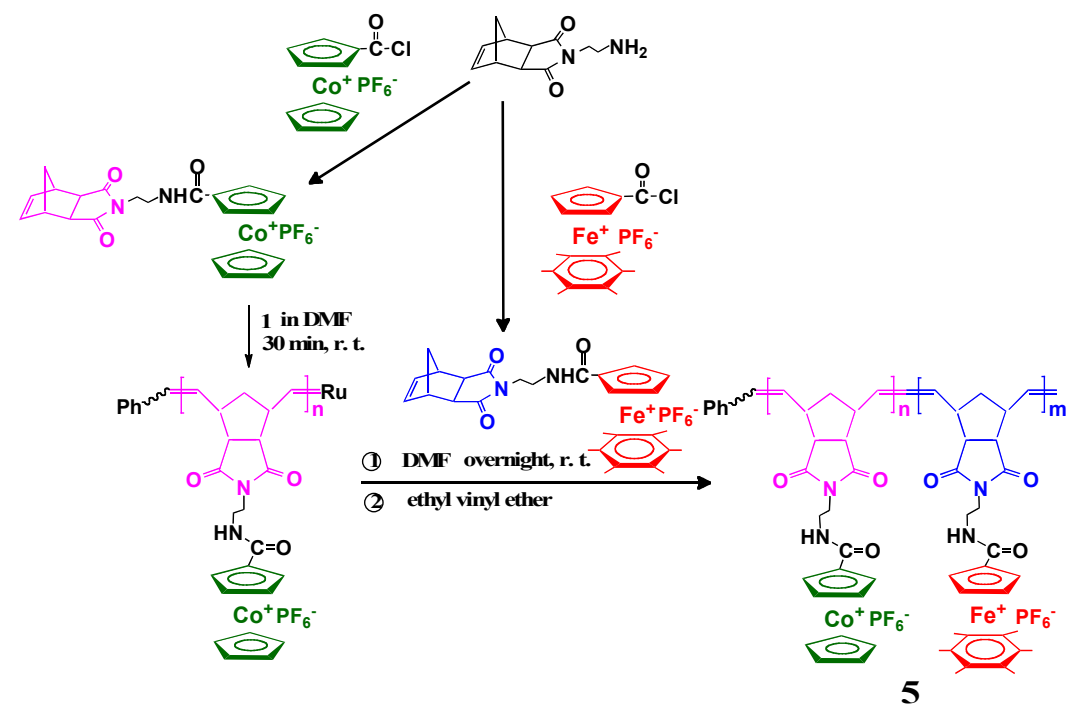

Scheme 5. ROMP synthesis of the diblock polyelectrolyte 5 containing a polymer block of 25 units of redox robust cobalticinium and a second polymer block containing 25 units of redoxrobust complex $\left[\mathrm{FeCp}\left(\mathrm{h}^{6}-\mathrm{C}_{6} \mathrm{Me}_{6}\right)\right]\left[\mathrm{PF}_{6}\right][41 \mathrm{e}]$.

The rich reversible electrochemistry and electron-transfer chemistry of late transition-metal sandwich complexes allows conducting and monitoring a number of electron-transfer reactions for both analytical [4,8b,52-54] (including sensing [54]) and synthetic purposes 
[4,8b]. Cyclic voltammetry allows determining the number of metallocene units in the metallopolymers using the empirical Bard-Anson method [53]. The presence of redox-robust metallocenes in polymers allows for instance oxidation of a neutral polymer to a polycationic polyelectrolyte polymer. This was achieved with pentamethylferrocene-containing polymers. Whereas ferricinium-containing polymers are thermally fragile and sensitive unless they are stereoelectronically stabilized, pentamethylferricinium-containing polymers are robust due to cyclopentadienyl permethylation of one ring while the other $\mathrm{Cp}$ ring bears the functional group containing the linker to the polymer. An additional property is the stabilization of gold nanoparticles in such polyelectrolytes [41c].

\section{Metallocene-containing dendrimers}

Metallocene-containing dendrimers have attracted interest since the early days of dendrimer chemistry [55], in particular for their functions as sensors [12,13,19a] and catalysts $[12,13,56,57]$, and the field has been largely reviewed $[12,13,56]$. Here only new aspects are evoked from the recent chemistry of our research group. Click metallodendrimers were pioneered in 2007 including their sensor and catalytic functions [15,57] (Figure 2). The key property of these dendrimers is the presence of intradendritic 1,2,3-triazole groups that are potential ligands for transition-metal cations. These ligands allow possible redox recognition and sensing of these cations by cyclic voltammetry if ferrocene or cobalticinium groups are attached to the triazolyl rings at the dendrimer branch termini, because the shift of the redox potential of the metallocenes due to the triazole-cation complexation depends on the nature of the cation.

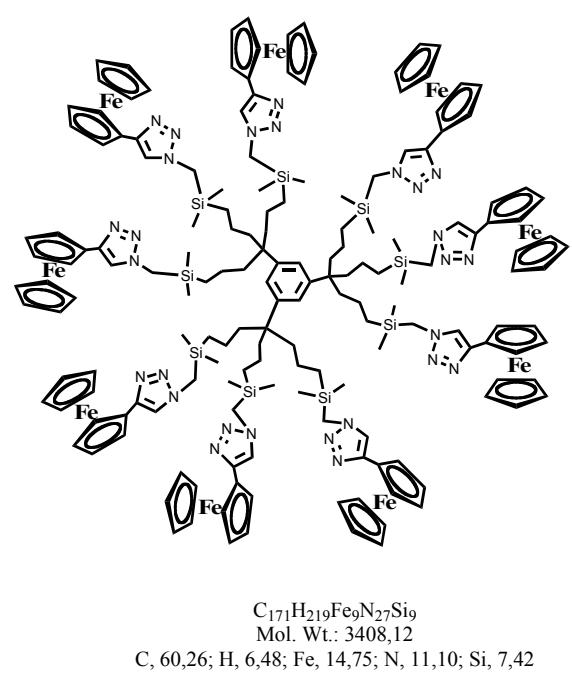

Figure 2. Molecular structure and analytical characteristics of the zeroth generation dendrimer, first member of a series of poly(ferrocenyltriazolyl) dendrimers serving as templates for intradendritic transition-metal cation complexation to the triazoles [15a].

It is also possible to let the dendrimer react with a stoichiometric amount of transition-metal cation that will coordinate all the triazole ligands inside the dendrimer, then to reduce these 
cations to transition-metal nanoparticles by reaction with $\mathrm{NaBH}_{4}$. This kind of strategy was pioneered by Crooks' group using PAMAM dendrimers with applications in catalysis [58]. In our case, it appears that the complexation of the intradendritic triazole ligands to the surface of the nanoparticles is smoother than in PAMAM dendrimer, making nanoparticle catalysis extremely efficient. If the dendrimer is large enough, the nanoparticle is located inside the dendrimer, whereas if the dendrimer is small (zeroth-generation), for instance with nine branches, then the nanoparticle is larger than the dendrimer, and several dendrimer molecules stabilize each nanoparticle. In both cases, the transition-metal nanoparticle is stabilized and catalytically active. For instance such Pd nanoparticles are very active for various carboncarbon cross coupling reactions including the Miyaura-Suzuki, Sonogashira and Heck reactions, and such Au nanoparticles are active for 4-nitrophenol reduction to 4-aminophenol. Recently, click metallodendrimers with $\mathrm{C}_{5} \mathrm{Me}_{5} \mathrm{Fe}(\mathrm{dppe})$, ferrocene, biferrocene and cobalticinium termini were reported with and without intradendritic triazole rings. The functions involved were also redox recognition and late transition-metal nanoparticle formation resulting from complexation by transition-metal cations followed by reduction [59]. Not only was the presence of intradendritic triazole essential for redox sensing of late transition-metal cations and oxo-anions, but also the size of nanoparticle obtained and their catalytic activity showed the crucial role of the presence of intradendritic ligands for the encapsulation of catalytically active nanoparticles. Transition-metal nanoparticles formed in the absence of intradendritic triazoles were much larger than those formed according to the number of complexed intradendritic triazoles, because nanoparticles form outside the dendrimer without intradendritic restriction if there are no intradendritic triazole ligands. The advantage of the presence of transition-metal-sandwich redox sites close to the triazoles is that these sites sense the triazole complexation by cations and anions [57]. Recently new metallocenyl dendrimers were synthesized also using $1 \rightarrow 3$ connectivity [60], but with shorter dendrons in which the allyl groups were directly located on a silicon atom generating a much more compact dendrimer structure than previously using a long phenol- $p$-triallylmethyl linker between two generations (Scheme 6). Interestingly, the very small Pd nanoparticles formed intradendritically upon $\mathrm{NaBH}_{4}$ reduction of $\mathrm{Pd}^{\mathrm{II}}$ species coordinated to the intradendritic triazoles were considerably less catalytically active in the Miyaura-Suzuki cross carboncarbon coupling of bromobenzene with phenylboronic acid than when the dendrimer of same generation and tether number was constructed using the longer dendron [59c]. This dichotomy sheds light on the key role of the length of the dendron tethers used in the dendrimer construction in view of further nanoparticle catalytic efficiency.

Finally, another strategy for the construction of ferrocenyl dendrimer-stabilized catalytically active $\mathrm{Pd}$ nanoparticles involved dendrimer assembly around the nanoparticle using nonaferrocenyl dendrons bearing a thiol focal point. The peripheral bulk of 8 (Figure 3) resulting from the presence of the ferrocenyl termini minimizes the number of coordinated dendrons and creates both a large void for the introduction of substrates and free coordination sites for their catalytic activation on the Pd nanoparticle surface. In spite of the reputation of thiols to inhibit catalytic reactions, the dendrimer $\mathbf{8}$ was shown to be an excellent nanoparticle catalyst. Indeed, the dendrimer $\mathbf{8}$ was catalytically active for the Miyaura-Suzuki coupling of bromoarenes with phenylboronic acid and the hydrogenation of styrene under $1 \mathrm{~atm} \mathrm{H}_{2}$ at room temperature [59d]. 


\section{Concluding remarks.}

The presence of redox-robust metallocenyl groups in block metallocopolymers and metallodendrimers allows switching the solubility and various other physical properties $[41,57,59]$ including the catalytic activity of the metallomacromolecules $[61,62]$. Intradendritic triazole ligands formed by click construction of the macromolecules offers the possibility of metal cation complexation for catalysis and further of reduction to metal nanoparticles that present excellent catalytic activities. In addition, the dendrimer topology provides better encapsulation creating a specific intradendritic confinement for efficient catalysis even in water. The dual strategies of dendrimer catalyst anchoring and dendrimer encapsulation may be compared in terms of catalytic efficiency and selectivity, greenness, and facility of catalyst synthesis [62]. In this review, the advantages of nanoparticles have been indicated, but catalysis with minute catalyst amounts also include intradendritically encapsulated metal cations, in particular in the click (CuAAC) reactions [63]. 

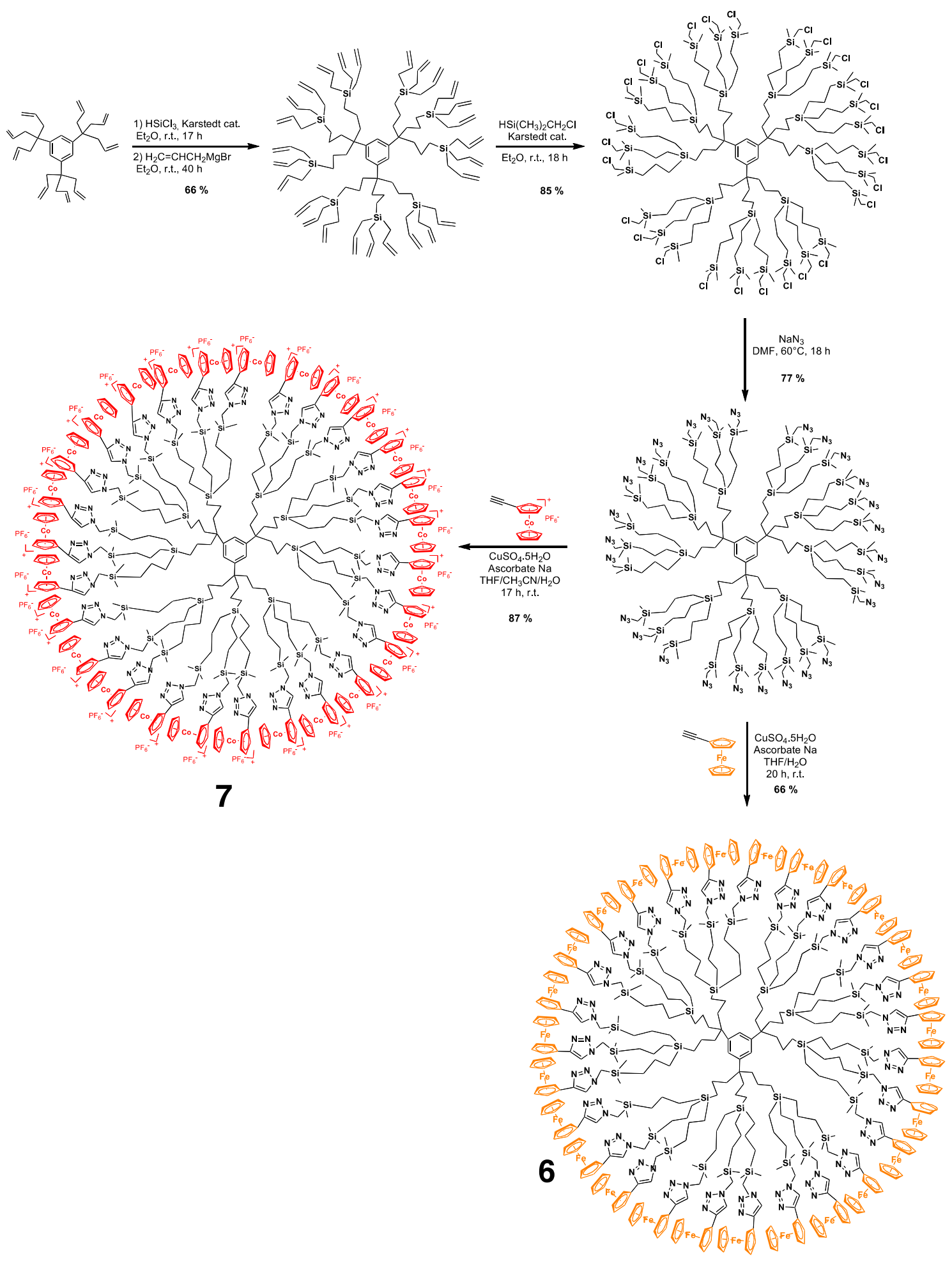

Scheme 6 . Synthesis of the metallodendrimers 6 and 7 with $1 \rightarrow 3$ connectivity and short tethers resulting in compact triazolylmetallocene peripheries [59c] 


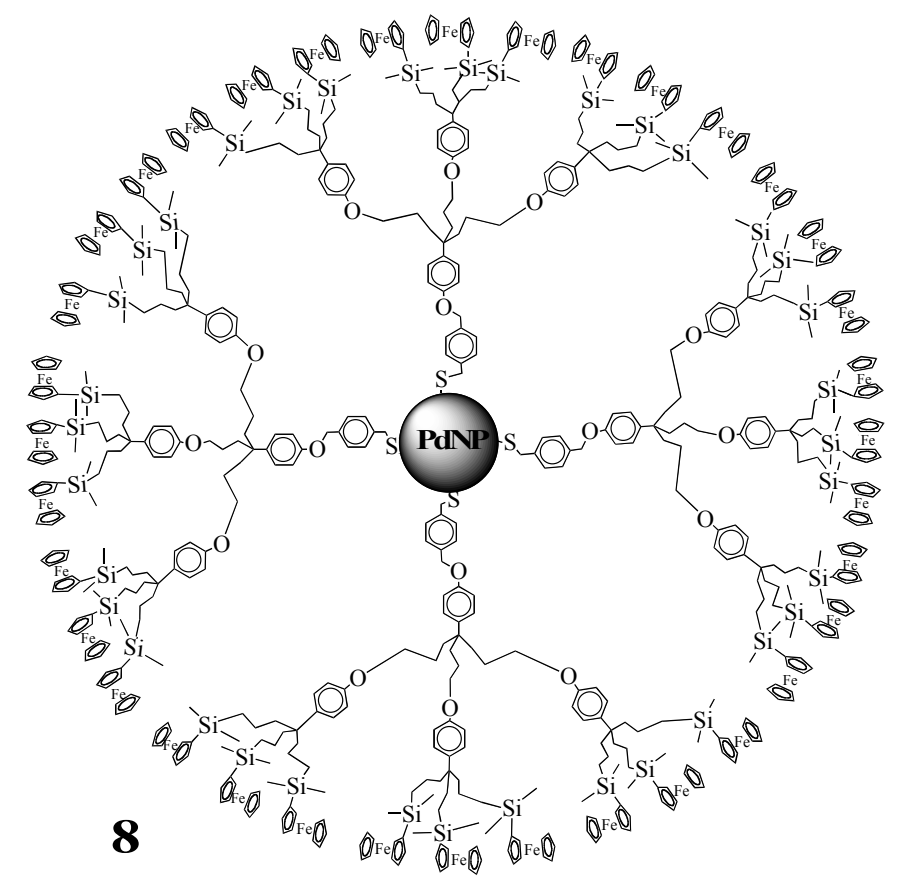

Figure 3. Catalytically active Pd nanoparticle-cored ferrocenyl-terminated dendrimer 8 containing bulky nonaferrocenyl dendron with thiolate focal points binding the $\mathrm{Pd}$ nanoparticle core [59d].

\section{Acknowledgements}

Excellent contributions to the work reviewed in this article by colleagues and students cited in the references and financial support from the Universities of Bordeaux, Sichuan at Chengdu and Basque Country, the National Science Foundation of China (21106088), the PhD program Foundation of the Ministry of Education of China (HG, China, 20110181120079), the Gobierno Vasco (RC, Spain) the Centre National de la Recherche Scientifique (CNRS), the Institut Universitaire de France (DA, IUF), and the Agence Nationale de la Recherche (ANR) are gratefully acknowledged.

\section{References}

[1] (a) E. O. Fischer, W. Pfab, Z. Naturforsch B 7 (1952) 377-379;

(b) G. Wilkinson, M. Rosenblum, M. C. Whiting, R. B. Woodward, J. Am. Chem. Soc. 74 (1952) 2125-2126;

(c) P. Lazlo, R. Hoffmann, Angew. Chem. Int. Ed. 39 (2000) 123-124;

(d) P. Stepnicka. Ferrocenes: Ligands, Materials and Biomolecules. Wiley, Hoboken, 2008;

(e) Ferrocenes, A. Togni, T. Hayashi Eds., Wiley-VCH, Weinheim, 2008;

(f) H. Werner, Angew. Chem. Int. Ed. 51 (2012) 6052-6058.

[2] F. S. Arimoto, A. C. Haven, Jr., J. Am. Chem. Soc. 77 (1955) 6295-6297. 
[3] D. Astruc. Organometallic Chemistry and Catalysis, Springer, Berlin, 2007.

[4] (a) W. E. Geiger, J. Organomet. Chem. Libr. 23 (1990) 142-172;

(b) N. G. Connelly, W. E. Geiger, Chem. Rev. 96 (1996) 877-910;

(c) W. E. Geiger, Organometallics 26 (2007) 5738-5765.

[5] (a) H. Nishihara, Adv. Inorg. Chem. 53 (2002) 41-86;

(b) P. Zanelo. Inorganic Electrochemistry: Theory, Practice and Applications. RSC, Cambridge, U. K., 2003.

[6] (a) A. Hildebrandt, D. Shaarschmidt, H. Lang, Organometallics 30 (2011) 556-563;

(b) A. Hildebrandt, H. Lang, Organometallics 32 (2013) 2993-3002.

[7] (a) N. C. Foulds, C. R. Lowe, Anal. Chem. 60 (1988) 2473-2478;

(b) P. D. Hale, L. I. Boguslasvky, T. Inagaki, H. I. Karan, H. S. Lee, T. A. Stokheim, Y. Okamoto, Anal. Chem. 63 (1991) 677-682;

(c) A. Heller, J. Phys. Chem. 96 (1992) 3579-3587.

[8] (a) J. Ruiz; F. Ogliaro, J.-Y. Saillard, J.-F. Halet, F. Varret, D. Astruc, J. Am. Chem. Soc. 120 (1998) 11693-11705;

(b) D. Astruc, Electron Transfer and Radical Processes in Transition Metal Chemistry, VCH, New York, 1995;

(c) H. Taube, foreword in ref. $8 \mathrm{~b}$.

[9] D. E. Herbert, U. F. J. Mayer, I. Manners, Angew. Chem. Int. Ed. 46 (2007) 5060-5081.

[10] (a) I. Manners, Synthetic Metal-Containing Polymers; Wiley-VCH: Weinheim, Germany, 2004;

(b) G. R. Whittell, I. Manners, Adv. Mater. 19 (2007) 3439-3468;

(c) A. S. Abd-El-Aziz, I. Manners. Frontiers in transition-metal containing polymers (Wiley, New York, 2007).

[11](a) A. S. Abd-El-Aziz, C. Agatemor, N. Etkin, Macromol. Rapid. Commun. 35 (2014) 513-559;

(b) I. Dragutan, V. Dragutan, P. Filip, B. C. Simionescu, A. Demonceau, Molecules 21(2) (2016) 198.

[12] (a) C. M. Casado, I. Cuadrado, M. Morán, Coord. Chem. Rev. 185-6 (1999) 53-80;

(b) C. M. Casado, B. Alonso, J. Losada, M. P. Garcia-Armada, In "Designing Dendrimers”, S. Campagna, P. Ceroni, F. Puntoriero Eds., Wiley, Hoboken, N. J., USA, pp. 219-262.

[13] (a) D. Astruc, E. Boisselier, C. Ornelas, Chem. Rev. 110 (2010) 1857-1959;

(b) D. Astruc, Nat. Chem. 4 (2012) 255-267.

[14] I. Dragutan, V. Dragutan, B. C. Simionescu, A. Demonceau, H. Fischer, Beilstein J. Org. Chem. 11 (2015) 2747-2762.

[15] C. Ornelas, J. Ruiz, E. Cloutet, S. Alves, D. Astruc, Angew. Chem. Int. Ed. 46 (2007) 872-877.

[16] (a) C. W. Bielawski, R. H. Grubbs, Prog. Polym. Chem. 32 (2007) 1-29;

(b) I. Dragutan, V. Dragutan, H. Fischer, J. Inorg. Organomet. Polym. Mater. 18 (2008) 311-324;

(c) C. Deraedt, M. d'Halluin, D. Astruc, Eur. J. Inorg. Chem. (2013) 4881-4908;

(d) A. C. Knall, C. Slukovc, In. Olefin Metathesis. Theory and Practice, K. Grela Ed., Wiley, Hoboken, N. J., USA., 2014, pp. 269-284; 
(e) R. H. Grubbs, A. G. Wenzel, Eds.; Handbook of Metathesis, Volume 1: Catalyst Development and Mechanism, 2nd ed.; Wiley-VCH: Weinheim, Germany, 2015.

[17] (a) S. Lastella, Y. J. Jung, H. Yang, R. Vajtai, P. M. Ajayan, C. Y. Ryu, D. A. Rider, I. Manners, J. Mater. Chem. 14 (2004) 1791-1794;

(b) J. Q. Lu, T. E. Kopley, N. Moll, D. Roitman, D. Chamberlin, Q. Fu, J. Liu, T. P. Russell, D. A. Rider, I. Manners, M. A. Winnik, Chem. Mater. 17 (2005) 2227-2231.

[18] (a) D. J. Caruana, A. Heller, J. Am. Chem. Soc. 121 (1999) 769-774;

(b) N. Gajovic, G. Binyamin, A. Warsinke, F. W. Scheller, A. Heller, Anal. Chem. 72 (2000) 2963-2968.

[19] (a) C. Valério, J.-L. Fillaut, J. Ruiz, J. Guittard, J.-C. Blais, D. Astruc, J. Am. Chem. Soc. 119 (1997) 2588-2589;

(b) M.-C. Daniel, J. Ruiz, D. Astruc, J. Am. Chem. Soc. 125 (2003) 1150-1151;

(c) R. Djeda, A. Rapakousiou, L. Liang, N. Guidolin, J. Ruiz, D. Astruc, Angew. Chem. Int. Ed. 49 (2010) 8152-8156.

[20] M. Péter, R. G. H. Lammertink, M. A. Hempenius G. J. Vancso, Langmuir 21 (2005) 5115-5123.

[21] Y. Ma, W.-F. Dong, M. A. Hempenius, H. Möhwald, G. J. Vancso, Nat. Mater. 5 (2006) 724-729.

[22]D. P. Puzzo, A. C. Arsenault, I. Manners, G. A. Ozin, Angew. Chem. Int. Ed. 48 (2009) 943-947.

[23] (a) C.-A. Fustin, B. G. G. Lohmeijer, A.-S. Duwez, A. M. Jonas, U. S. Schubert, J.-F. Gohy, Adv. Mater. 17 (2005) 1162 - 1165;

(b) I. Korczagin, R. G. H. Lammertink, M. A. Hempenius, S. Golze, G. J. Vancso, Adv. Polym. Sci. 200 (2006) 91 - 117;

(c) J. Lu, D. Chamberlin, D. A. Rider, M. Liu, I. Manners, T. P. Russell, Nanotechnology 17 (2006) 5792-5797.

[24] (a) D. A. Rider, K. Liu, J.-C. Eloi, L. Vanderark, L. Yang, J.-Y. Wang, D. Grozea, Z.-H. Lu, T. P. Russell, I. Manners, ACS Nano 2 (2008) 263-270;

(b) B. Djukic, T. Seda, S. I. Gorelsky, A. J. Lough, M. T. Lemaire, Inorg. Chem. 50 (2011) 7334-7343;

(c) B. Özkale, E. Pellicer, M. A. Zeeshan, J. F. López-Barberá, J. Nogués, J. Sort, B. J. Nelson, S. Pané, Nanoscale 6 (2014) 4683-4690.

[25] (a) X. Bao, Q. Zhao, H. Wang, K. Liu, D. Qiu, Inorg. Chem. Commun. 38 (2013) 88-91;

(b) A. Et Taouil, J. Husson, L. Guyard, J. Electroanal. Chem. 728 (2014) 81-85.

[26] (a) K. Liu, S. Fournier-Bidoz, G. A. Ozin, I. Manners, Chem. Mater. 21 (2009) 17811783 ;

(b) J. Kong, M. Kong, X. Zhang, L. Chen, L. An, ACS Appl. Mater. Interfaces 5 (2013) 10367-10375.

[27] (a) A. S. Abd-El-Aziz, P. O. Shipman, B. N. Boden, W. S. McNeil, Prog. Polym. Sci. 35 (2010) 714-836;

(b) I. Manners, J. Organomet. Chem. 696 (2011) 1146-1149;

(c) X. de Hatten, N. Bell, N. Yufa, G. Christmann, J. R. Nitschke, J. Am. Chem. Soc. 133 (2011) 3158-3164.

[28] (a) D. A. Foucher, B. Z. Tang, I. Manners, J. Am. Chem. Soc. 114 (1992) 6246-6248; 
(b) P. Nguyen, P. Gomez-Elipe, I. Manners, Chem. Rev. 99 (1999) 1515-1548;

(c) I. Manners, Science 294 (2001) 1664-1666;

(d) For a recent review on the developments of strained metallocenophane, see: A. D.

Russel, R. A. Musgrave, L. K. Stoll, P. Choi, H. Qiu, I. Manners, J. Organomet. Chem.

784 (2015) 24-30.

[29] D. Astruc, L. Liang, A. Rapakousiou, J. Ruiz, Acc. Chem. Res. 45 (2012) 630-640.

[30] C. Deraedt, A. Rapakousiou, Y. Wang, L. Salmon, M. Bousquet, D. Astruc, Angew.

Chem. Int. Ed. 53 (2014) 8445-8449

[31] N. Hadjichristidis, M. Pitsikalis, S. Pispas, H. Iatrou, Chem. Rev. 101 (2001) 3747-3792. [32] M. R. Buchmeiser, Chem. Rev. 100 (2000) 1565-1604.

[33] (a) K. Matyjaszewski, J. Xia, Chem. Rev. 101 (2001) 2921-2990;

(b) M. Kamigaito, T. Ando, M. Sawamoto, Chem. Rev. 101 (2001) 3689-3746.

[34] (a) J.-S. Wang, K. Matyjaszewski, J. Am. Chem. Soc. 117 (1995) 5614-5615;

(b) V. Percec, B. Barboiu, Macromolecules 28 (1995) 7970-7972;

(c) M. Kato, M. Kamigaito, M. Sawamoto, T. Higashihara, Macromolecules 28 (1995) 1721-1723.

[35] J. Zhang, L. Ren, C. G. Hardy, C. Tang, Macromolecules 45 (2012) 6857-6863.

[36] C. J. Hawker, A. W. Bosman, E. Harth, Chem. Rev. 101 (2001) 3661-3688.

[37] (a) R. R. Schrock, Acc. Chem. Res. 23 (1990) 158-165;

(b) R. R. Schrock, In Handbook of Metathesis Vol. 1: Catalyst Development and Mechanism, 2nd ed.; R. H. Grubbs, A. G. Wenzel, Eds.; Wiley-VCH: Weinheim, Germany, 2015; pp. 1-32.

[38] (a) M. S. Sanford, J. A. Love, R. H. Grubbs, Organometallics 20 (2001) 5314-5318;

(b) G. C. Vougioukalakis, R. H. Grubbs, Chem. Rev. 110 (2010) 1746-1787;

(c) G. C. Vougioukalakis, Ruthenium-Benzylidene Olefin Metathesis Catalysts. In Olefin Metathesis: Theory and Practice; K. Grela, Ed.; John Wiley \& Sons: Hoboken, NJ, USA, 2014; pp. 397-416.

[39] Y. Zha, H. D. Thaker, R. R. Maddikeri, S. P. Gido, M. T. Tuominen, G. N. Tew, J. Am. Chem. Soc. 134 (2012) 14534-14541.

[40] (a) C. G. Hardy, L. Ren, J. Zhang, C. Tang, Isr. J. Chem. 52 (2012) 230-245;

(b) C. G. Hardy, L. Ren, S. Ma, C. Tang, Chem. Commun. 49 (2013) 4373-4375;

(c) C. G. Hardy, J. Zhang, Y. Yan, L. Ren, C. Tang, Progr. Polym. Sci. 39 (2014) 17421796.

[41] (a) H. Gu, A. Rapakousiou, P. Castel, N. Guidolin, N. Pinaud, J. Ruiz, D. Astruc Organometallics 33 (2014) 4323-4335;

(b) H. Gu, R. Ciganda, R. Hernández, P. Castel, P. Zhao, J. Ruiz, D. Astruc, Macromolecules 48 (2015) 6071-6076;

(c) H. Gu, R. Ciganda, P. Castel, A. Vax, D. Gregurec, J. Irigoyen, S. Moya, L. Salmon, P. Zhao, J. Ruiz, R. Hernández, D. Astruc, Chem. Eur. J. 21 (2015) 18177-18186;

(d) R. Ciganda, H. Gu, P. Castel, P. Zhao, J. Ruiz, R. Hernández, D. Astruc, Macromol. Rapid Commun. 37 (2016) 105-111;

(e) H. Gu, R. Ciganda, P. Castel, P. Zhao, J. Ruiz, R. Hernández, D. Astruc, Macromol. Rapid Commun. 37 (2016) DOI: 10.1002/marc.201500679.

[42] (a) G. Wilkinson, J. Am. Chem. Soc. 74 (1952) 6148-6149; 
(b) J. E. Sheats, M. D. Rausch, J. Org. Chem. 35 (1970) 3245-3249;

(c) B. Gloaguen, D. Astruc, J. Am. Chem. Soc. 112 (1990) 4607-4609

[43] (a) A. K. Diallo, S. Menuel, E. Monflier, J. Ruiz, D. Astruc, Tetrahedron Lett. 51 (2010) 4617-4619;

(b) A. Rapakousiou, C. Mouche, M. Duttine, J. Ruiz, D. Astruc, Eur. J. Inorg. Chem. (2012) 5071-5077;

(c) Y. Wang, A. Rapakousiou, C. Latouche, J.-C. Daran, A. Singh, I. Ledoux-Rak, J. Ruiz, J.-Y. Saillard, D. Astruc, Chem. Commun. 49 (2013) 5862 - 5864

[44] (a) L. Ren, C. G. Hardy, G. Christopher, C. Tang, J. Am. Chem. Soc. 132 (2010) 88748875 ;

(b) L. X. Ren, J. Y. Zhang, C. G. Hardy, S. G. Ma, C. B. Tang, Macromol. Rapid Commun. 33 (2012) 510-516;

(c) Y. Wang, A. Rapakousiou, J. Ruiz, D. Astruc, Chem. Eur. J. 20 (2014) 11176-11186.

[45] A. S. Abd-El-Aziz, S. Bernardin, Coord. Chem. Rev. 203 (2000) 219-267.

[46] (a) M. V. Rajasekharan, S. Giezynski, J. H. Ammeter, N. Oswald, J. R. Hamon, D. Astruc, P. Michaud, J. Am. Chem. Soc. 104 (1982) 2400-2407;

(b) M. Lacoste, F. Varret, L. Toupet, D. Astruc, J. Am. Chem. Soc. 109 (1987) 65046506;

(c) M.-H. Desbois, D. Astruc, J. Guillin, F. Varret, A. X. Trautwein, G. Villeneuve, J. Am. Chem. Soc. 111 (1989) 5800-5809;

(d) J. Ruiz, M. Lacoste, D. Astruc, J. Am. Chem. Soc. 112 (1990) 5471-5483.

[47] (a) A. S. Abd-El-Aziz, Macromol. Rapid Commun. 23 (2002) 995-1031;

(b) A. S. Abd-El-Aziz, E. K. Todd, Coord. Chem. Rev. 246 (2003) 3-52;

(c) A. S. Abd-El-Aziz, I. Manners, J. Inorg. Organomet. Polym. Mater. 15 (2005) 157195;

(d) A. S. Abd-El-Aziz, E. A. Strohm, Polymer 53 (2012) 4879-4921;

(e) A. S. Abd-El-Aziz, C. Agatemor, N. Etkin, Macromol. Rapid. Commun. 35 (2014) 513-559;

(f) A. S. Abd-El-Aziz, C. Agatemor, N. Etkin, D. P. Overy, M. Lanteigne, K. McQuillan, R. G. Kerr, Biomacromolecules 16 (2015) 3694-3703;

(g) C. Agatemor, N. Etkin, A. S. Abd-El-Aziz, J. Inorg. Organomet. Polym. Mater. 25 (2015) 47-63.

[48] (a) T. P. Gill, K. R. Mann, Inorg. Chem. 19 (1980) 3007-3010;

(b) D. Catheline, D. Astruc, J. Organomet. Chem. 248 (1983) C9-C12;

(c) D. Catheline, D. Astruc, J. Organomet. Chem. 272 (1984) 417-426.

[49] (a) C. Moinet, E. Roman, D. Astruc, J. Electroanal. Chem. and Interf. Electrochem. 121 (1981) 241-253;

(b) J. C. Green, M. R. Kelly, M. P. Payne, E. A. Seddon, D. Astruc, J. R. Hamon, P. Michaud, Organometallics 2 (1983) 211-218.

[50] J.-R. Hamon, D. Astruc, P. Michaud, J. Am. Chem. Soc. 103 (1981) 758-766;

[51] A. Madonik, D. Astruc, J. Am. Chem. Soc. 106 (1984) 2437-2439.

[52] A. J. Bard, L. R. Faulkner, Electrochemical Methods: Fundamentals and Applications, 2nd ed. Wiley, New York 2001. 
[53] J. B. Flanagan, S. Margel, A. J. Bard, F. C. Anson, J. Am. Chem. Soc. 100 (1978) 42484253.

[54]P. D. Beer, P. A. Gale, Angew. Chem. Int. Ed. Engl. 40 (2001) 486-516.

[55] I. F. Moulines, D. Astruc, Angew. Chem. Int. Ed. Engl. 27 (1988) 1347-1349.

[56] (a) G. R. Newkome, E. He, C. N. Moorefield, Chem. Rev. 99 (1999) 1689-1746 ;

(b) S.-H. Hwang, C. D. Shreiner, C. N. Moorefield, G. R. Newkome, New J. Chem. 31 (2007) 1192-1217.

[57] A. K. Diallo, C. Ornelas, L. Salmon, J. Ruiz, D. Astruc, Angew. Chem. Int. Ed. 46 (2007) 8644-8648.

[58] (a) R. M.; Crooks, M. Zhao, L. Sun, V. Chechik, L. K. Yeung, Acc. Chem. Res. 34 (2001) 181-190;

(b) R. W. J. Scott, O. M. Wilson, R. M. Crooks, J. Phys. Chem. B 109 (2005) 692-704.

[59] (a) Y. Wang, L. Salmon, J. Ruiz, D. Astruc, Nat. Commun. 5 (2014) number 3489;

(b) A. Rapakousiou, Y. Wang, C. Belin, N. Pinaud, J. Ruiz, D. Astruc, Inorg. Chem. 52 (2013) 6685-6693;

(c) S. Gatard, C. Deraedt, A. Rapakousiou, D. Sonet, L. Salmon, J. Ruiz, D. Astruc, Organometallics 34 (2015) 1643-1650;

(d) F. Lu, D. Astruc, Eur. J. Inorg. Chem. (2015) 5595-5600.

[60] (a) G. R. Newkome, Z.-Q. Yao, G. R. Baker, V. K. Gupta, J. Org. Chem. 50 (1985) 20032004;

(b) G. R. Newkome, C. Shreiner, Chem. Rev. 110 (2010) 6338-6442.

[61] A.-M. Caminade, A. Ouali, R. Laurent, C.-O. Turrin, J.-P. Majoral, Coord. Chem. Rev. 308 (2016) 478-497.

[62] D. Astruc, Tetrahedron Asym. 21 (2010) 1041-1054.

[63] C. Deraedt, N. Pinaud, D. Astruc, J. Am. Chem. Soc. 136 (2014) 12092-12098. 